\title{
LINGUISTICS IN LEGAL COMMUNICATION: LANGUAGE, COMMUNICATION, TEXT, LAW
}

\author{
Julia Pisulińska, \\ University of Warsaw, Poland, \\ student of Applied Lingustics: German and English \\ j.pisulinska@student.uw.edu.pl \\ Mentor: Joanna Osiejewicz, \\ University of Warsaw, Poland \\ j.osiejewicz@uw.edu.pl
}

Abstract. The paper encompasses such fields as language, communication, text, law in terms of legal communication. According to language, I try to define the language itself as well as the linguistic focusing mainly on accomplishments of De Saussure. Secondly, it was introduced the subject of communication and its history while taking into consideration the purpose of the paper: legal communication. Legal communication is based on juridical language and legal language. I discussed them and emphasised distinctions between them. This part of the paper, which I can describe as an introduction part, ends with an indication of the research on the field of legal communication.

The second part deals in general with communication and problems concerning this matter. I paid attention to the problem of communicativeness, because this matter is not as easy to be provided in legal communication as it seems to be. I moved on to the text as a part of legal communication, its main assumptions which by scholars are perceived as unable to be fulfilled and levels of interpretation this kind of text. This topic is followed by the issue of terminology which is the key to understand the text relating to law. Then I come back to the language, however, this time I point out the command of Polish language, its culture and the language of law stressing aspects regarding correctness. I decided also to include the subject of legal translation which apart from the issues mentioned above needs the specialised knowledge. The final part presents the main thoughts and my conclusions noticing the mutual influence between presented areas as well as the general need of expanding knowledge specifically in relation to language and law.

Keywords: legal communication, language, law, text,

The term "linguistics" comes from the Latin word "lingua", meaning language. Franciszek Grucza, who is considered to be the father of applied linguistics, perceives linguistics as a science dealing with human languages and distinguishes its two types: theoretical linguistics and applied linguistics (Grucza, 2017). Ferdinand de Saussure can be regarded as the precursor of linguistics itself, giving lectures on the subject which were later collected by his colleagues in the book, Course in General Linguistics. However, in the context of this work, the focus is on what defines this field, that is language. According to de Saussure, 
language is defined as a system of signs containing a signified and a signifier, meaning a signified and a signifying party. Over the years, the direction in which language is defined has changed considerably. An achievement that occurred in the 1970s may be revealing. Since then, a linguistic paradigm called communicationism has dominated. It was due to the concepts contained in the Prague School and generative-transformative grammar. It exceeded what was proposed by structuralism initiated earlier by de Saussure. He focused only on the sign-to-sign relation, whereas communicationism presents other relations based on the pragmatic and semantic aspect. The former shows the relations: sign-users and the psychocultural context of the sign, while the latter: sign-thought and reality. Thus, it is not only a study of the system, but also of linguistic communication and the text as a means of this communication. This does not mean, however, that the concept established earlier, i.e. structuralism, does not have its place in research and common consciousness. Both thoughts exist simultaneously creating a kind of ambiguity in linguistic research. This concerns the very notion of language, which can be defined in many ways (Gajda, 2004).

The concept of communicationism is extremely important in relation to the second issue discussed, that is communication. This act is realised if the goal, which in this case is in most situations the transmission of a message, is successfully realised and comes into being by means of language, writing, printing or the mass media (Kulczycki, 2012). Through them, it is produced in spoken and written form. The way information is exchanged is considered to be "primarily auditory, while the written form is secondary" (Olejniczak, 2018). The reason for this is that speech was the first to emerge and only later did people make use of symbols by transferring them onto writing materials. However, the fact is that communication has been around since ancient times and had its function long before the appearance of symbols (Kulczycki, 2012). Consequently, communication existed before the emergence of law, and generally of customary norms, which were the source of the origin of legal norms in antiquity. It played its role, also in the context of the later Mesopotamian, Hebrew or Greek law (Sójka-Zielińska, 2015). Already at that time, language, nowadays called legal language, was inextricably linked with communication in this field.

It is worth emphasising the distinction between juridical and legal language because, contrary to the common assertion, these two terms describe separate phenomena. In the last century, Bronisław Wróblewski attempted to define these terms. Juridical language is perceived as the language of normative acts issued by organisations with law-making competences. It belongs to the group of specialised languages, as a distinct community gathers around this particular system of signs. This means that the sender and the receiver are representatives of a group that has the skills to understand this code. By contrast, legal language is the one used by legal practitioners (Olejniczak, 2018). It includes the language of judicial and non-judicial practice, and jurisprudence (Gajda, 2004). Adam W. Olejniczak states that it should be intended as a bridge between juridical and colloquial language, between the legislator and the recipient of the law - the citizen (Olejniczak, 2018). It can be seen that juridical language functions as the superior language, while legal language is its derivative. The division may, however, go further than the one proposed by Wróblewski and encompassing only one central language and the other being its derivative (Olejniczak, 2018). Others that are also inseparable from law sometimes include: the distinctive 
language of legal rules and norms, the language of practice, doctrine (dogmatics), colloquial legal language (Brodziak, 2004). To this already extensive group should also be added the statements of representatives of higher state bodies, citizens, journalists, legal scholars, lawyers applying the law, other entities applying the law, school headmasters, chairmen of company boards, entities adjudicating in judicial and administrative proceedings, mayors, governors, etc. (Zieliński, 2004). These senders of messages are undoubtedly a very diverse group. It is a fact, however, that, for example, a journalist and a lawyer, although they probably formulate their statements in different ways, both use the language of law for this purpose. Nevertheless, there are doubts about this initial distinction, as well as about the much more specific one. It has not been resolved whether these languages can be understood as (de Saussure's distinction) "langue”, i.e. in linguistic terms (Brodziak, 2004).

It can be concluded that some linguistic issues concerning law, legal communication or various related areas have still not been clarified. However, there have been attempts to study the problems which constitute interesting scientific material, have still not been resolved, or the analysis of a given topic seems to be unsatisfactory to the researcher. The process of research on the language of law in Poland was particularly slow in the last century, and a real breakthrough occurred only at the end of the century. Jurisprudence is eager to refer to the matters concerning language, not limiting itself to strictly legal phenomena. This research to a large extent requires reference to the heritage of linguistics, which legal scholars are more and more willing to do (Zieliński, 2004). Linguists in particular, however, have expressed their interest in this area through analyses and theoretical texts (Śliwicka, 2018). This has only been happening recently. Previously, the scholars shunned the scientific study of this sphere, and if they produced analyses on this subject, they were often superficial and critical. Nowadays the main focus is on the communicative-linguistic sphere (Gajda, 2004).

The key to success in research may be the collaboration of the two communities. The two disciplines belong to the humanities and social sciences, which already provides a nucleus of common similarities. Stanisław Gajda mentions that "it would be worthwhile (to concentrate these interests in juridical language) by creating a certain organisational framework" (Gajda, 2004). It would make even more sense for this research to translate into everyday interaction between law and linguistics. Law is always linguistic in nature it is difficult to imagine that it would exist without words. It is believed that this function concerning a set of signs can be described as equally important as the regulatory function. In German, there is even a special expression referring to this: Sprachlichkeit des Rechts. In Poland, the research and development of this field has not allowed the creation of its own term, and perhaps it would be worth considering its domestic equivalent (Nieciecka, 2014).

A real problem that lawyers have been facing for many years is communicativeness. It is worth asking how the concept of communicativeness is understood. The word can be defined as "the ability to reach the recipient in the process of communication, to communicate; clarity, expressiveness". The key element of this definition is understanding. It is the absolute goal of the process of mutual communication. This result is achieved when both parties demonstrate linguistic competence, which is how statements are formed in a certain language, and communicative competence, which is based on demonstrating the 
ability to send and receive content (Chodun, 2009). The principle of relaying the clearest possible legal message to the public has long been on the agenda, but has largely remained unfulfilled (Gizbert-Studnicki, 2009). The blame for the current state of affairs lies on both parties. One party are lawyers, who often do not have the sufficient communicative and linguistic competence. There is no denying that they sometimes use legal language knowing that the recipient will not understand them. Then they focus on themselves, on what they want to convey, forgetting that the person who is obliged to read the message has no chance of doing so because of the characteristic way in which the statement is constructed and saturated with specialist terminology. A legal background would be necessary for laymen to understand what such a statement means. There is, however, a lack of such training in our country, and this state of affairs is not likely to change. The only solution therefore would be to make the message more comprehensible from a linguistic and communication point of view (Gajda, 2004). Such a proposal seems feasible, provided that both parties are willing to do so. Certainly, the intervention of linguists, who are most familiar with the language that is the source of the misunderstandings in this situation, could assist in this matter.

One type of communication, previously named secondary mode of communication, is text. It is used to establish legal norms (Lizisowa, 2009). Its essence is therefore to impose or enable a given course of action. It is created by legislators who decide on all the elements relating to the content and style of these written expressions (Malinowski, 2020). The value of legislative texts is assessed by whether it is characterised by following: precision, conciseness and unambiguity (Choduń, 2009). In his book, however, Tomasz GizbertStudnicki argues that text comprehensibility stands in opposition to these three pillars. Conciseness may be crucial when it comes to the interpretation of a legal text. When it is not maintained, there is a chance that the recipient would arbitrarily read the content, deeming some passages redundant. When the aim is for non-legal readers to understand the text, according to many examples, it automatically becomes longer. Another contentious issue is unambiguity, which is essentially linked to precision. Both these characteristics refer to the language of the law. This is because it is characterised by specialised terminology, which avoids ambiguity. For a text to be understood by a wide audience, it would have to resort to natural language, which creates ambiguities in terms of meaning at the lexical and syntactic level (Gizbert-Studnicki, 1986). The appropriate interpretation of the information encoded in written juridical language by many participants in the communication process is related to universality. It is important that the text reaches as many recipients as possible. Only then can it be considered to have been adequately understood, in accordance with what the author intended to convey. Moreover, it is ultimately expected that the recipient will not need to consult specialised sources of knowledge (Nieciecka, 2014). This would only hinder the layman's aspiration to learn about legal norms and create a negative attitude towards further contact with this field. In addition, the person whose task it is to produce legislation often fails to make clear their intentions, what they want to convey through a given text to the reader (Gizbert-Studnicki, 1986). It can therefore be deduced that achieving the ideal consensus between unambiguity, precision, conciseness and comprehensibility is a challenge for lawyers. 
With legal texts, also as with oral utterances, there is a demand for communicative competence, which the senders and receivers should possess. An essential feature of a legal text as an utterance is unidirectionality - the lawyer communicates the content to the person. The recipient should be aware that their task is to correctly interpret the information read out. This is done on two levels: descriptive and normative (Choduń, 2009). The former focuses on the world in which the written creation functions. This world abounds in things, events, behaviour. The recipient becomes acquainted with it in the course of literal reading of the text (Sarkiewicz, 2004). However, it would be wrong to treat this level as equal to a literary text. The common element connecting these two types of written expression is certainly the description of the world, but in the case of legal writing it does not contain such elements as action, persons, place, time, reasons or goals. There are only fragments reminiscent of a literary work. These include, among others, a description of the course of a trial or content focusing on the sequence of action, the person of the protagonist (Sarkiewicz, 2004). The normative level, on the other hand, deals with legal norms and often poses many difficulties for the layman (Jabłoński, 2020). In order to read it, the ability to correctly interpret the content is undoubtedly required (Sarkiewicz, 2004). The average citizen has problems with the reconstruction of laws and with the legal system in general (Choduń, 2009). Both levels function together. It is difficult to separate them from each other and to focus, for example, only on the literal reading. It is not true that first the literal meaning of a text has to be acquainted in order to perceive its normative character. This belief is based on the thesis that the descriptive account of legal norms can be understood as more primary. This refers to the question of the independent functioning of description. In order to read a text literally, it is not necessary to look at its normative character. Norms or directives, however, are inherent in the description of a certain reality (Sarkiewicz, 2004). People live though in a world in which most of them do not have a satisfactory knowledge of how to interpret a text correctly in normative terms.

In the general characterisation of the problem, it is also worth including the issues of terminology. Each law-related text contains terms that do not appear in everyday spoken language. Interestingly, even for some lawyers these terms may seem foreign. This is because law is divided into many sub-fields which are usually characterised by their own specific terminology. The main difficulties related to lexis that may be encountered by the recipient relate to semantic differences and the introduction of new, specialised terms. There are many words in law which are used by laymen. However, their knowledge is not sufficient to interpret the text correctly. It should be remembered that these terms change their meaning and, in their new context, refer specifically to law. There are many reasons and purposes for such transformations within existing terms. However, it should not be forgotten that they must be clear to the recipient and their use rationally justified. Sometimes it happens that those new meanings are a form of disrespect or lack of knowledge that a given expression has already been used in another way (Sobczak, 2017). In this matter, as in many others, the general knowledge of law, mentioned many times before, is also significant. New concepts are most often created in order to name specific institutions, which do not function within the common language (Matulewska, 2009). These terms usually enter the language through legal definitions, are presented in case law practice or legal science, and occur naturally in the Polish language. 
Many text-related concerns are raised by legal scholars' problems with language. The competence is divided into exemplary and satisfactory. The former applies primarily to the specialists. The sender-legislator and the recipient-interpreter characterised as experts in this field should have sufficient knowledge of the principles of legislative and interpretative technique and have a very good command of language (Malinowska, 2004). This is by no means only about the command of Polish, but also about its culture. Professor Hanna Jadacka, a linguist, stresses that the errors appearing in legal texts do not relate solely to grammar, but largely focus precisely on the culture of the mother tongue (Sobczak, 2017). There are many definitions of this concept. In general, there are three commonly accepted elements to which the culture of the Polish language refers: the value of the means of communication, correctness and cultural-linguistic activity. Linguists concerned with the culture of language determine what is considered a proper form or not (Kubicka, 2014). Correctness in legal texts must be maintained on two levels. The first concerns general language, the second, the Polish juridical language (Malinowski, 2020). This correctness is of great importance in law, although it often cannot be achieved, because it conflicts with the previously mentioned postulates of unambiguity, precision and conciseness. It is therefore necessary to ensure that the text is consistent with the Polish language, at the same time realising that the Polish language used there will not always be perfect.

However, linguistics is not only about the Polish language. More and more people are choosing foreign languages for their future. Professionals who use a sign system other than their mother tongue often choose translation as their career path. It may be general or specialised translation, or simultaneous or consecutive interpretation, and above all it may concern many areas. Legal translation is considered to be a specific type of the art of translation. It essentially requires knowledge of many areas and is therefore interdisciplinary. The core of this is, of course, the mother tongue, the knowledge of which is expected to be at a proficient level. Secondly, a translator must have a perfect command of the target language. The quality of legal translation may be determined by the translator's knowledge. Such a person needs to demonstrate a wealth of information within legal systems and general legal reality. Additionally, it is worth noting that jurists usually have knowledge of a specific field of law. A translator, even a specialised one, usually deals with various legal texts. The knowledge of translation studies, translation techniques may become helpful in transforming work from the source language to the target language. The minimum areas of knowledge that a translator should have are therefore four areas of science (Matulewska and Gortych, 2009). Unfortunately, even the extensive competences of a translator are not always enough to achieve success. Significant obstacles may be created by differences in the language of law. The source and target languages are usually based on different legal systems, which makes it difficult to translate many terms correctly. Difficulties may include the equivalence of the names of law enforcement agencies, the names of the judiciary, the names of court procedures, the names of juridical and legal documents, the names of legal institutions or common expressions, which are very common in law. There is no simple solution to this situation. The translator is obliged to check exactly what the meaning of a particular term is in the legal system. It is then worth consulting parallel texts. Legal writings often have established conventions, which makes it possible to compare them with others 
already existing in the target language (Kubacki, 2019). This requires additional work on the part of the translator, but there is no denying that, overall, translation itself is a complex process. In this case, the saying 'practice makes perfect' certainly applies.

Law lives in language and through language (Nieciecka, 2014). In conclusion, the special role of linguistics, and more specifically of linguists in each of the aspects presented, is what concludes this paper. In this paper, the lawyer-layman relationship has been mentioned in relation to the communication process. Both parties need linguistic and communicative competence, in which experts in the medium of speech are specialised, in order to convey and read the message properly. The linguistic heritage can contribute much to a better understanding between them. In the matter of the text, which has been discussed at length, communication proceeds unilaterally-the lawyer conveys the information necessary to the citizen. It is the lawyer who is responsible for ensuring that the text is unambiguous, concise, precise, correct and, above all, comprehensible. As has been emphasised, the legal professional often finds this a largely impossible challenge to meet. However, nothing stands in the way of trying to achieve the goal of finally making the recipients look kindlier on the texts in this field. This seems particularly important in terms of correctness. Lawyers' linguistic prowess is generally based only on what they have mastered throughout their lives. They do not pay attention to improve their knowledge of the rules and standards of the given means of communication, focusing primarily on the substantive content. Professionalism requires appropriate use of language, especially since their task is very often to create writing. The written form of expression is expected to have better formulated thoughts, to be structured, to follow grammatical, syntactic and semantic rules. It is also necessary to remember about the appropriate terminology, which will allow for precise expression of the content. "Verba volant, scripta manent" - spoken words fly away, written words remain. Lawyers' texts demonstrate their knowledge and skills. A specific form of legal communication, largely relating to texts, is translation. It would seem that the art of translating content from the source language into the target language depends primarily on the knowledge of both sign systems. This common misconception devalues the work of translators. It omits extremely important parts, such as the knowledge of a given field, in this case the knowledge of a vast and sometimes complicated law. The complexities of terminology and of the legal system itself require work and effort that are not always noticed.

Because of the many links between linguistics and law, it is worth considering sound linguistic education. In particular, it is important for specialist training to include the language of law. The familiarisation with language, however, should apply not only to lawyers, but to all citizens, since each person has to manage communication. In fact, a person never knows when he or she will be confronted with a problem relating to law. General education in this area would therefore be appropriate. These two fields cannot be separated from each other. Communicative competence in the field of law always requires two factors: the knowledge covering this science and the efficient use of language (Malinowska, 2004). 


\section{REFERENCES}

Brodziak, K. (2004). 0 lingwistycznym statusie języka prawnego. In: E. Malinowska, Język- prawospołeczeństwo (pp. 61-75). Opole: Wydawnictwo Uniwersytetu Opolskiego.

Choduń, A. (2009). Uwagi o komunikatywności tekstów aktów prawnych. In: A. Mróz, A. Niewiadomski \& M. Pawelec (Eds.), Prawo i język (pp. 127-131). Warszawa.

Gajda, S. (2004). Język administracyjno-prawny w perspektywie językoznawczej i prawoznawczej. In:

E. Malinowska (Eds.), Język- prawo- społeczeństwo (pp. 19-31). Opole: Wydawnictwo Uniwersytetu Opolskiego. Gizbert-Studnicki, T. (2009). Postulat jasności i zrozumiałości tekstów prawnych a dostęp do prawa. In:

A. Mróz, A. Niewiadomski \& M. Pawelec (Eds.), Prawo i język (pp. 37-48). Warszawa.

Gizbert-Studnicki, T. (1986). Język prawny z perspektywy socjolingwistycznej, Warszawa-Kraków: Państwowe Wydawnictwo Naukowe.

Grucza, F. (2017). Lingwistyka stosowana. Historia-Zadania-Osiagnięcia, Warszawa: Wydawnictwo

Naukowe Instytutu Komunikacji Specjalistycznej i Interkulturowej Uniwersytetu Warszawskiego.

Jabłoński, P. (2020). O ideologicznym poziomie interpretacji tekstu prawnego. Przegląd prawa $i$ administracji CXXII, 122, 39-54.

Kubacki, A. D. (2019). Podstawowe trudności w przekładzie tekstów prawnych. Artykuły po konferencji: Prawo i język prawa- współczesne dylematy.

Kubicka, E. (2014). Kultura języka w praktyce prawniczej- co?, po co?, jak?. In: D. Kala \& E. Kubicka (Eds.), Kultura języka polskiego w praktyce prawniczej (pp. 34-52).

Kulczycki, E. (2012). Teoretyzowanie komunikacji, Poznań: Wydawnictwo Naukowe Instytutu Filozofii UAM.

Lizisowa, T. M. (2009). Performatywne wypowiedzi prawne w aspekcie lingwistyki tekstu. In: A. Mróz,

A. Niewiadomski \& M. Pawelec (Eds.), Prawo i język (pp. 19-36). Warszawa.

Malinowska, E. (2004). Wzorce wypowiedzi urzędowych a ich realizacja. In: E. Malinowska (Eds.), Językprawo-społeczeństwo (pp. 143-150). Opole: Wydawnictwo Uniwersytetu Opolskiego.

Malinowski, A. (2020). Błędy formalne w tekstach prawnych, Warszawa: Wolters Kluwer Polska.

Matulewska, A. (2009). Problemy przekładu terminologii wieloznacznej występującej w polskich tekstach. In: A. Mróz, A. Niewiadomski \& M. Pawelec (Eds.), Prawo i język (pp. 85-94). Warszawa.

Matulewska, A. \& Gortych, K. (2009). Translacyjne problemy wyrażania modalności deontycznej w tekstach aktów normatywnych w języku polskim, angielskim i greckim. In: A. Mróz, A. Niewiadomski \& M. Pawelec (Eds.), Prawo i język, (pp. 65-78). Warszawa.

Nieciecka, K. (2014). Kilka uwag o problematyce komunikatywności tekstów prawnych. Studenckie Prace Prawnicze, Administratywistyczne i Ekonomiczne, 16, 107-124.

Olejniczak, A. W. (2018). Język prawny w prawie polskim. Ustawodawca dla profesjonalistów czy obywateli? In: A. Jakuszewicz (Eds.), Język i prawo (pp. 27-45). Bydgoszcz: Wydawnictwo Uniwersytetu Kazimierza Wielkiego.

Sarkiewicz, R. (2004). Koherencja tekstu prawnego w świecie koncepcji poziomowej interpretacji. In: E. Malinowska (Eds.), Język- prawo- społeczeństwo (pp. 49-60). Opole: Wydawnictwo Uniwersytetu Opolskiego.

Sobczak, K. (2017, July 17). Język narzędziem komunikacji prawodawcy ze społeczeństwem. Prawo.pl. Retrieved from: https://www.prawo.pl/prawnicy-sady/jezyk-narzedziem-komunikacji-prawodawcy-zespoleczenstwem,71259.html

Sójka-Zielińska, K. (2015). Historia prawa, Warszawa: Wolters Kluwer Polska.

Śliwicka, A. (2018). Język prawny i język prawniczy jako przedmiot badań językoznawczych i prawoznawczych w latach 1935-1999. Prace Językoznawcze, 20(3), 151-164.

Zieliński, M. (2004). Język prawny, język administracyjny, język urzędowy. In: E. Malinowska (Eds.), Językprawo- społeczeństwo (pp. 9-18). Opole: Wydawnictwo Uniwersytetu Opolskiego. 